Transactions of the Karelian Research Centre of the Russian Academy of Sciences

No. 7. 2021. P. 6-15

DOI: $10.17076 /$ them 1471
Труды Карельского научного центра РАН

№ 7. 2021. С. 6-15

УДК 502(1-751.1)(470.1/.2)

\title{
IMPLEMENTATION OF THE IDEA OF THE GREEN BELT OF FENNOSCANDIA AS A SYSTEM OF PROTECTED AREAS IN THE EUROPEAN NORTH
}

\author{
O. N. Bakhmet ${ }^{1}$, A. M. Kryshen'1, E. A. Borovichev ${ }^{2}$, A. N. Gromtsev', \\ A. V. Kravchenko', O. L. Kuznetsov' ${ }^{1}$, A. F. Titov' ${ }^{1}$, O. V. Petrova ${ }^{2}$, \\ V. A. Masloboev² \\ ${ }^{1}$ Karelian Research Centre, Russian Academy of Sciences, Petrozavodsk, Russia \\ ${ }^{2}$ Kola Science Centre, Russian Academy of Sciences, Apatity, Russia
}

\begin{abstract}
The Green Belt of Fennoscandia (GBF) is the Russian-Finnish-Norwegian border region with forest areas and mire massifs almost unaffected by human activity. In the early 1990s, the concept of the Green Belt of Fennoscandia was put forward as a result of joint work of researchers and experts in Fennoscandia and discussion of sustainable development principles for border regions. Its main aim was to have public interests united in the fields of economic development and nature conservation. The cores of the GBF are protected areas (PAs), of federal and regional status, and ecologically connected with the PanEuropean Ecological Network (Natura 2000) as well as with Norwegian PAs.
\end{abstract}

Ke y w o rd s: Fennoscandia; Green Belt; protected areas; border regions; cooperation; convergence of research approaches; PA network.

\section{О. Н. Бахмет, \\ А. М. Крышень, \\ Е. А. Боровичев, \\ А. Н. Громцев, А. В. Кравченко, \\ О. Л. Кузнецов, \\ А. Ф. Титов, \\ О. В. Петрова, \\ В. А. Маслобоев. \\ РАЗВИТИЕ \\ КОНЦЕПЦИИ \\ ЗЕЛЕНОГО ПОЯСА \\ ФЕННОСКАНДИИ - СИСТЕМЫ ОХРАНЯЕМЫХ ПРИРОДНЫХ ТЕРРИТОРИЙ НА ЕВРОПЕЙСКОМ СЕВЕРЕ}

Зеленый пояс Фенноскандии (ЗПФ) - российско-финляндско-норвежская приграничная территория с фрагментами лесных и болотных массивов, мало затронутых антропогенной деятельностью. В начале 1990-х годов с расширением международного сотрудничества ученых и специалистов и обсуждения принципов устойчивого развития приграничных территорий возникла концепция Зеленого пояса Фенноскандии, основная идея которой - сочетание интересов общества в экономическом развитии и сохранение природы. Ключевыми участками ЗПФ являются особо охраняемые природные территории (ООПТ) как федерального, так и регионального подчинения, экологически связанные с Пан-Европейской экологической сетью (Natura 2000) и с ООПТ Норвегии.

Ключевые слова: Фенноскандия; Зеленый пояс; особо охраняемые природные территории; приграничные территории; сотрудничество; гармонизация научно-исследовательских подходов; сеть ООПт. 
The Green Belt of Fennoscandia (GBF) stretches along the borders between the Russian Federation, Finland and Norway. Unlike adjacent wide areas heavily transformed by human activities, the region boasts relatively intact forest and mire massifs (Fig. 1-2).

\section{Establishment of the PA Network}

In the 1990s, Russian and Finnish researchers noticed than the territory along the national border remained almost intact, which could be explained by the region's poor accessibility and, partly, by the strict border regime. The idea was put forward to establish a number of large-scale protected areas (PAs) in close proximity to the border, not only expanding the Russian PA network but also connecting it to Finnish parks [Titov et al., 1995]. As a result, the GBF was created. Unlike the then discussed politicized idea of the European Green Belt, the GBF concept was mainly aimed at nature conservation. Its main goal was to establish and develop the PAs network along the border, ensure more efficient management of natural resources to preserve the unique natural heritage and maintain environmental sustainability.

The GBF idea has been moving progressively by taking concrete steps towards the fulfillment of its mission. Since the mid-1990s, a number of research programmes and projects have been implemented. They received support from the European Union and Finland. With participation of researchers from KarRC RAS, more than 20 projects for nature inventories and feasibility studies for planned PAs in the Republic of Karelia were accomplished in the framework of the Russian-Finnish "Development Programme on Sustainable Forest Management and Conservation of Biodiversity in NorthWest Russia". Among them: "Biodiversity inventory and study in the Republic of Karelia" (1997-2002); "Feasibility study and inventory of the Kalevalsky National Park territory" (1997-1998); "Feasibility study and inventory of the Tulos National Park territory" (1997-1998); "Feasibility study and inventory of the Koitajoki National Park territory" (1997-1998). Simultaneously, studies were carried out to develop the network of Karelian PAs within the TACIS programme. They were also aimed at environmental education and ecotourism development [Antonova et al., 2005; Gromtsev et al., 2014, etc.].

The inventory of biodiversity along the $700-\mathrm{km}$ border line between Karelia and Finland, and in an over 400-km border stretch between the Murmansk Region and Finland and Norway proved the feasibility of establishing several large PAs there. Their spatial scope, boundaries, and protection regimes were defined with regard to their specific landscapes and environment. Besides, special attention was given to the consistency of the planned parks and reserves with the PAs network on the Finnish side. The work done can, in fact, be said to be unparalleled, at least in what concerns forest regions in Russia. Moreover, all the significant research results have been promptly published [Inventory..., 1998-2001; Biotic..., 2003].

During the first stage, thirty individual nature objects (many of them with no official protection status) were outlined in Russia in the GBF territory. They stretched as a narrow strip (20-30 km on average) along the Russian-Norwegian and RussianFinnish borders. These forest and mire areas were marked out as being well preserved, owing not only to the strict border zone regime in the Soviet times but, mainly, to the lack of roads and large settlements. By 1998, the number of the proposed areas was reduced to twenty. The number included only existing and planned PAs of federal and regional status. Later on, by 2003 , based on the experience obtained when preparing other nominations for PAs, the number of areas suggested for inclusion in GBF on the Russian side was cut down to eight. Five of them already had a federal PA status (4 strict nature reserves (SNR), 1 national park (NP)), and three had claims for the NP status. Some of them were integrated with Finnish and Norwegian PAs to form several transboundary complexes (Pasvik - Vatsari, Laplandsky Les Jonn-Nyugoaiv - Urho Kekkonen, Kutsa - Paanajarvi - Oulanka, Kalevalsky Complex, "Friendship" Park, Ladoga Skerries - Saimaa and Pielinen).

\section{The role of GBF in the development of cooperation in border regions}

The GBF runs along national borders, which do not coincide with ethnic boundaries. It comprises areas rich in indigenous peoples' traditions (suffice it to mention runic traditions and the "Kalevala" epic). Thus, another priority alongside nature conservation, is the identification of ethno-cultural cores and substantiation of measures to preserve local traditions and languages, as well as historical and cultural monuments. This goal is essential not only for maintaining the cultural identity, but also for establishing the prerequisites for sustainable economic development of border regions [Morozova et al., 2001; Morozova, 2005; Druzhinin, 2006]. As has been said, people are coming to the understanding that nature conservation can be economically beneficial. National parks and nature reserves (zakazniks) are to turn into centres of ecotourism and sources of economic growth in their neighbou- 


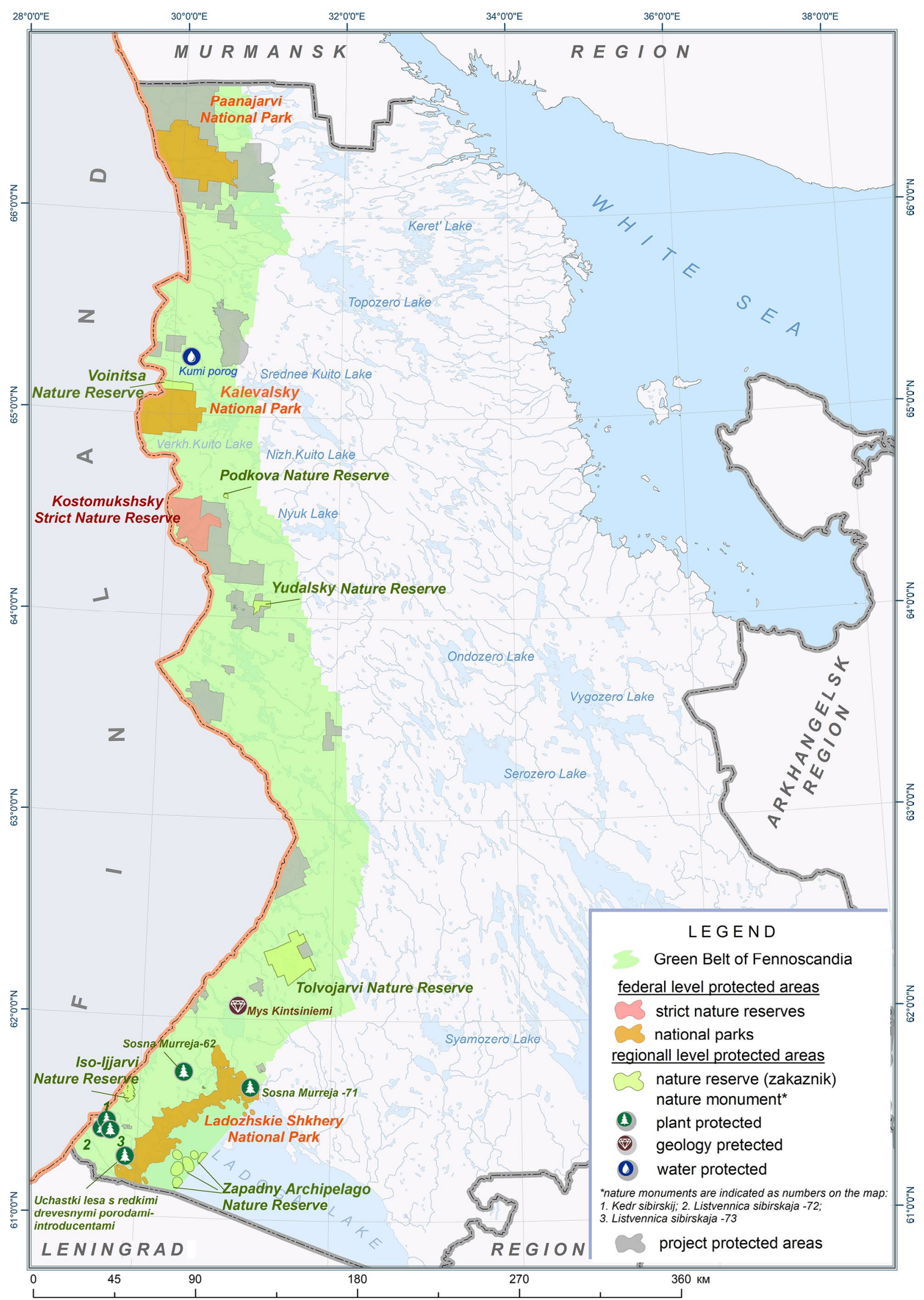

Fig. 1. Green Belt of Fennoscandia along the borders of the Murmansk Region of Russia with Finland and Norway 


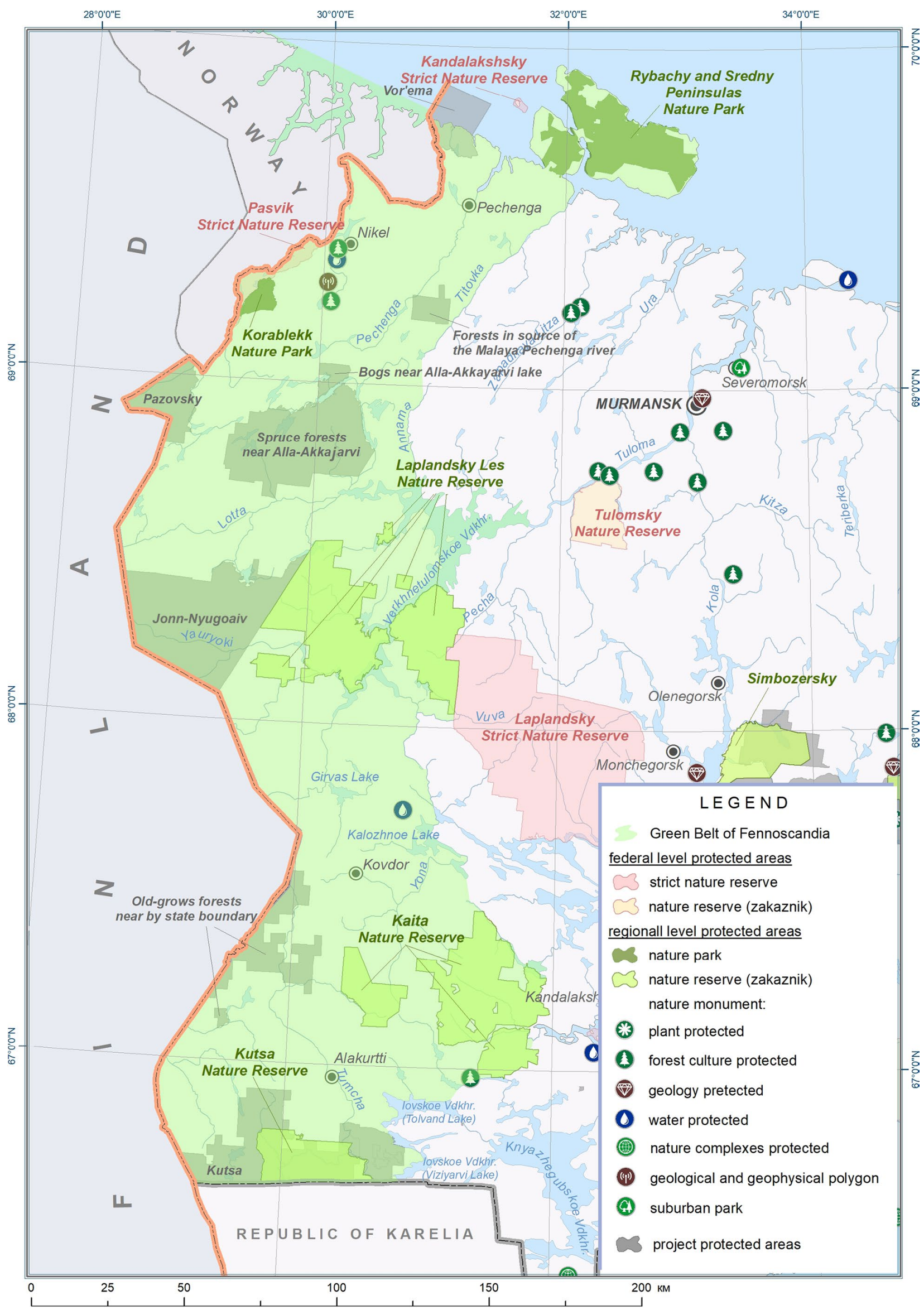

Fig. 2. Green Belt of Fennoscandia along the border between the Republic of Karelia and Finland 
hoods. Implementation by researchers from KarRC RAS of the international project "IntellGreenBelt" ("Intellectually driven management of natural resources of the Green Belt of Fennoscandia") under the ENPI Cross-border Cooperation programme 2012-2014 has contributed to the development of transboundary solutions both for the conservation and reproduction of natural resources and for the invigoration of socio-economic activities on both sides of the border (including learning tourism). Border regions are a potential platform for working out and promoting social, humanitarian, environmental projects and technologies on both sides of the border, thus demonstrating a novel aspect of a socially oriented innovative scenario of regional and local development.

Thus, it should be noted that European countries pay a growing attention to healthy environment, environment-friendly industrial technologies, environmental standards, and that demand for organic food among European consumers is increasing. In this connection, the usually low level of economic development, low population density and insufficient land use in borderland Karelia can and should be regarded not only as a shortcoming, but at the same time as a strong competitive advantage and potential for socio-economic development.

\section{Convergence of Russian and European research approaches and methods}

Convergence of research approaches and methods across borders may be considered as one of the most notable achievements of international joint projects. This is reflected e. g. in shared scientific databases on biodiversity and various natural resources of regions. The range of participating specialists and organizations has expanded markedly. There appeared projects devoted to ecotourism development in border regions. Presently, the data obtained and the expert networks on all sides of the border can provide for scientifically grounded decision-making for the development of specific regions. In 2000-2008, funding of the projects concerning border regions increased due to economic improvement in the Russian Federation. Foundations supporting Russian science (RFBR and RSF), the Programme "Biological Resources and Gene Pool Dynamics" of the RAS Presidium, the Programme "Biological Resources of Russia: Fundamentals of Sane Use" of the RAS Department of Biological Sciences have played and continue playing the leading role in this respect. As a result of these activities:

a) new data were obtained on species and community diversity, the resource potential of the region; b) intact ecosystems of exceptional nature conservation value (key areas) were identified;

c) the conditions for the survival and dispersal of rare species were studied, and measures for their protection were developed [Kravchenko et al., 2000; Gromtsev, 2001; Biotic..., 2003; Kurhinen et al., 2006; The Red..., 2007; Fedorets et al., 2009 etc.]. Besides, the economic potential of some border areas was studied and the main ways for their development were outlined; key objects of historical and cultural value were determined [Management..., 2008]. One of the essential outputs of federal and international projects has been the formation of research networks, which can comprehensively (based on the multidisciplinary approach) study a specific area and provide a multi-sided assessment of its development potential.

Regional authorities and various NGOs have lately become more active in nature protection activities. Since 2007, research institutes of KarRC RAS have been conducting the inventory of the Karelian PA network and developing the Geographical Information System (GIS) for these objects, ordered by the Ministry of Agriculture, Fisheries and Environment of the Republic of Karelia. This work has led to a gradual convergence of the opinions and positions of economic entities, scientific institutions and conservationist NGOs on issues concerning the management of natural resources. An overarching output of the assessments of the current state and representativeness of the PA network of Karelia is the feasibility study of the network development [Scientific..., 2009].

Compared to Karelia, the Murmansk Region joined the process somewhat later. Although the Murmansk stretch of GBF is over $400 \mathrm{~km}$, and the borderlands contain several operating and planned PAs, this extensive ecological corridor has not been comprehensively researched until lately, and even its boundaries have not been clearly outlined [Borovichev et al., 2018]. This has resulted, for instance, in the inclusion of the Lapland Strict Nature Reserve in early listings of GBF PAs [Titov et al., 2009], although the reserve is more than $130 \mathrm{~km}$ away from the border with Finland.

From 2007 to 2011, a large-scale project "GAP analysis in Northwest Russia" was implemented, its aim being to assess how representative the PA system of this large supraregion was. The project involved the Arkhangelsk, Vologda, Leningrad and Murmansk Regions, Republic of Karelia, and St. Petersburg. The results of these studies were published in 2011 in Russian and English [Mapping..., 2011]. The Murmansk Region PA network has also been analyzed for representative- 
ness of terms of plant diversity conservation [Diversity..., 2009]. As a follow-up of the project "GAP analysis in Northwest Russia", the concept of operation and development of the network of protected areas of the Murmansk Region until 2018 and further until 2038 was prepared. The concept was approved by Ordinance No 128-PP of the Murmansk Region Government dated 24.03.2011. Namely, this document stipulates the establishment of 11 various PAs in the border area.

\section{Current state of the PA network}

Quite a system of federal- (strict nature reserves (aka zapovedniks) and national parks) and regional-level (nature reserves (aka zakazniks) and nature monuments of various profiles) PAs, differing in the protection regimens regulated by endorsed standards, has already been established within GBF, and the planning process is still underway. The largest PAs in GBF are the following: national parks "Ladoga Skerries" (122,000 ha), "Kalevalsky" (74,400 ha), "Paanajarvi" (104,500 ha), nature parks "Rybachy and Sredniy Peninsulas" (83,100 ha) and "Korablekk" (8,300 ha), strict nature reserves "Kostomukshsky" (49,300 ha), "Kandalakshsky" (Ainovy Islands cluster) (1,220 ha), "Pasvik" (14,700 ha), landscape reserves "Beryozovye Islands" (53,600 ha), "Vyborgsky" (11,300 ha), "Iso-Jarvi" (6,100 ha), "Tolvojarvi" (41,900 ha), "Voinitsa" (8,400 ha), nature reserves "Zapadny Archipelago" (19,900 ha), "Laplandsky Les" (171,700 ha), "Kaita" (144,400 ha), "Kutsa" (52,000 ha). There also operate smaller conservation areas of various profiles, such as the geological nature monument "Cape Kintsiniemi", hydrological nature monument "Waterfall on the Shuonijoki River", landscape reserve "Yudalsky", landscape nature monument "Kumi Porog", and many others.

Another component not to be forgotten is waterside buffers with constraints on land use, which act as ecological corridors and connect PAs into an integral system. They are supposed to serve for wildlife migration and movements between PAs and other sites preserved in natural or semi-natural state thereby securing sustainable existence of the populations of various organisms.

A major constituent of the PA system in GBF is transboundary entities. The ones already operating are the Friendship Park, including Kostomukshsky Strict Nature Reserve on the Russian side and five conservation areas along the border on the Finnish side, covering in total ca. 80,000 ha. In 2014, the Kalevala Park was established in Finland (it consists of 19 sites with the total area of $30,000 \mathrm{ha}$ ). In the near future, it would be expedient to integrate the Kalevalsky National
Park and Voinitsa Landscape Reserve into this system, which would almost double the area. Another example is the planned Russian-Finnish protected area Oulanka-Paanajarvi, with Russian and Finnish national parks bearing the respective names and the Kutsa Regional Nature Reserve as its basis (totalling more than 130,000 ha in area). For over 20 years, there has been quite successful cooperation for the establishment of the trilateral Pasvik-Inari National Park at the border junction of Russia, Norway and Finland (Pasvik is its core). It has already obtained a Europarc certificate. Thus, managed cross-national entities made up of PAs are being established in the borderlands. In Finland, areas of top importance for GBF are also under statutory protection, i. a. under the national parks programme of Metsähallitus, old-growth forest conservation programme, and the pan-European environmental network $\mathrm{Na}$ tura 2000 [State..., 2007].

Current surveys of the extensive GBF territory detect valuable areas, for which feasibility studies for prospective PAs are prepared. Such are, first of all, the most scenic and recreationally attractive areas and sites: a) sandy and rocky lakeshores and riverbanks; b) narrow spit-like promontories and islands; c) large elevated areas offering a commanding view; d) esker ridges (especially narrow ones, between lakes); e) deep, canyon-like faults in the crystalline basement; f) rapid sections of rivers, etc. Sites with valuable biotopic characteristics (harboring concentrations of rare vascular plant species, pristine forest fragments, the most productive (elite) forest stands, etc.) must also be added to this listing.

The combined area of PAs forming the GBF backbone on the two sides of the Russian-Finnish border exceeds $1,000,000$ ha, of which 800,000 ha are on the Russian side. There are now plans to enlarge the area through addition of sites with relatively intact ecosystems to operating strict nature reserves and national parks, and by establishing some small nature reserves and nature monuments in Karelian borderlands. Thus, the phase of GBF development through mere enlargement of PA network size is nearing completion, and the focus is shifting towards organization of a unified, well-balanced system. One of the most promising lines of activity in this connection is identification and preservation in near-natural state of waterside buffers along rivers and lakes, forests and mires both within GBF and outside it. They can secure its connectivity with ecosystems in the Karelian White Sea area, Zaonezhye, and Archangelsk Region, and create the conditions for natural migration of animals and plants east to west and vice versa. 


\section{Transition from individual PAs to a holistic territory}

Vigorous scientific and civic activities within the formerly scattered international, federal and regional programmes and projects have gradually led to the understanding of the demand for the preparation and implementation of a special international GBF development programme. In June 2008, the international seminar "Green Belt of Fennoscandia: Status and Visions" took place in Petrozavodsk. Its participants discussed the key results of the work towards PA establishment in GBF in 1990-2000. Having discussed the materials, the seminar adopted the Resolution emphasizing that GBF development activities should be continued on the basis of a special programme with the following main objective: to create a holistic environmental-economic domain along RussianFinnish and Russian-Norwegian borders where the aim of conserving unique northern nature shall go along with the support and comprehensive development of the border territories taking into account their historical, ethno-cultural and economic characteristics.

The seminar and the following Russian-Finnish project gave an impetus to a new stage in the development of GBF and its recognition as one of key features of the environmental framework of the European North.

Apparently, the GBF is still a developing PA system. Strict nature reserves, national parks, and nature reserves of various profiles on both sides of the border enable the longitudinal movement of species and natural connectivity of areas exposed to human impacts differing in land use traditions, character and intensity.

In fact, one more GBF has formed by now, which almost entirely embraces the eastern boundaries of the Baltic Shield. There already exists a longitudinal chain of operating and planned PAs with most varied natural characteristics (with feasibility studies available). It runs from north to south, occupying a combined area of $1.4 \mathrm{mln}$. ha, excluding waterside buffers:

- along the White Sea coast

1) nature reserve (NR) Kolvitsky

2) nature reserve (NR) Kanozersky

3) strict nature reserve (SNR) Kandakakshsky

4) landscape reserve (LR) Polyarny Krug

5) landscape reserve (LR) Gridino [Rocky..., 2008]

6) landscape reserve (LR) Syrovatka [Inventory..., 2003]

7) landscape reserve (LR) Kuzova

8) landscape reserve (LR) Soroksky, etc.;
- along the border between the Republic of Karelia and the Archangelsk Region

9) national park (NP) Vodlozersky

10) landscape reserve (LR) Ypäussuo

11) landscape reserve (LR) Kozhosersky

12) landscape reserve (LR) Chukozero [Inventory..., 2007]

13) NP Kenozersky, etc.;

- along the border between the Republic of Karelia and the Vologda Region

14) landscape reserve (LR) Muromsky, LR Atleka, LR Verkhneandomsky, hydrological reserve (HR) Soidozero, etc.;

- along the border between the Vologda Region and the Leningrad Region

15) nature reserves Koloshemsky Les, Ratsa, Chagodoshchensky,

16) nature park (NP) Vepssky Les, etc., including protected mires.

It is safe to say that quite a representative and vast system of conservation areas has been taking shape in the periphery of Karelia (provided that the planned areas will be designated). It virtually encircles the region's western and eastern boundaries. In the south, the system is "looped in" along Lake Ladoga shore by SNR Nizhnesvirsky, waterside protection forests, planned National Park Ladoga Skerries, etc. Its northern contour is the comparatively narrow strip between the Gulf of Kandalaksha and the Russian-Finnish border (SNR Kandalakshsky, NR Kutsa, SNR Laplandsky). In essence, this PA system is the core of the nature protection framework of Eastern Fennoscandia. To make this framework even more robust, it is necessary to add several more PAs, arranged latitudinally, with taiga corridors leading outside of Fennoscandia towards large pristine forest massifs. In Karelia, of primary importance in this respect is designation of the planned Nature Park Zaonezhsky, which is connected in the west to the existing system via a waterside protection zone, reorganization of the Kutsa Nature Reserve into a nature park, and establishment of the Jonn-Nyugoaiv Nature Reserve.

An essential characteristic of the current phase in GBF development is that the idea has gone beyond the scope of science, and settled firmly in governmental documents of various levels. Thus, in 2010, the "Memorandum of Understanding on Cooperation on the Development of the Green Belt of Fennoscandia" was signed between the Ministry of the Environment of the Kingdom of Norway, the Ministry of the Environment of the Republic of Finland and the Ministry of Natural Resources and Environment of the Russian Federation. 
In 2013, an international conference was held in Petrozavodsk with the aim to consolidate the position of GBF as a holistic ecological-economic domain and to formulate new tasks for its development, including the delineation of GBF boundaries and official drawing up of GBF status, instatement of GBF as the key component of the North European PA system, priority setting for economic development in GBF, and preparation of the concept of GBF sustainable development as a region attractive to tourists and investors.

In 2017-2018, researchers from the Karelian Research Centre and Kola Science Centre of the Russian Academy of Sciences intensified their joint work to systematize available data on the natural conditions and biodiversity in GBF. These activities were supported by the Ministry of Natural Resources and Environment of the Russian Federation. The Project "Scientific substantiation of the creation and development of the Russian part of the protected areas network, which is unified with Norway and Finland" united the efforts of Karelia and Murmansk Region in creating the PA system along the Russian-Norwegian and Russian-Finnish national borders. The natural characteristics of the territory allow for implementation of the ECONET principle, i. e. a network of PAs and areas with land use restrictions interconnected by ecological corridors. The vast GBF territory traverses several biogeographical boundaries, unites different regions of Russia, and crosses the national borders of three countries. Importantly, there are good prospects for development both within the European Green Belt framework and within the North European PA system [Kryshen et al., 2012].

Furthermore, Russian experts believe that PAs included in an integrated serial transboundary object "Green Belt of Fennoscandia" satisfy all the requirements and criteria to be eligible for inscription in the UNESCO World Natural and Cultural Heritage List. On the other hand, they could, with time, turn into a kind of cores of planned biosphere reserves, and the European Green Belt in its northern section.

\section{References}

Antonova R. F., Belkin V. V., Gromtsev A. N. The history of nature management and the impact of human activity on the nature of Suojärvi district. Ed. A. N. Gromtsev. Petrozavodsk: KarRC RAS, 2005. 28 p. [In Russian]

Biotic diversity of Karelia: conditions of formation, community, species. Eds. A. N. Gromtsev, S. P. Kitaev, V. I. Krutov et al. Petrozavodsk: KarRC RAS, 2003. 262 p. [In Russian]
Borovichev E. A., Petrova O. V., Kryshen A. M. On the Fennoscandian Green Belt Boundaries in the Murmansk Region. Transactions of KarRC RAS. 2018. No. 8. P. 141-146. doi: 10.17076/bg770 [In Russian]

Diversity of plants, lichens, and cyanoprokaryota of Murmansk Oblast: study results and protection prospects. St. Petersburg, 2009. 120 p. [In Russian]

Druzhinin P. V. Forecasting of development of economy of border regions: methodological and methodical aspects. Transactions of KarRC RAS. 2006. No. 9. P. 67-83. [In Russian]

Gromtsev A. N. The most vulnerable forests in Karelia: characteristics, mapping, conservation measures. Petrozavodsk: KarRC RAS, 2001. 62 p. [In Russian]

Gromtsev A. N., Karpin V. A., Presnuhin Yu. V., Pet$\operatorname{rov} N$. V., Tuyunen A. V. Forest landscapes in the russian part of the Green Belt of Fennoscandia: natural features, current state and application. Transactions of KarRC RAS. 2014. No. 6. P. 39-52. [In Russian]

Inventory and study of biological diversity in central Karelia. Eds. A. N. Gromtsev, V. I. Krutov. Petrozavodsk: KarRC RAS, 2001. 250 p. [In Russian]

Inventory and study of biological diversity in Zaonezhie and Northern Ladoga Lake. Eds. A. N. Gromtsev, V. I. Krutov. Petrozavodsk: KarRC RAS, 2000. 150 p. [In Russian]

Inventory and study of biological diversity on the Karelian coast of the White Sea. Eds. A. N. Gromtsev, V. I. Krutov. Petrozavodsk: KarRC RAS, 1999. 140 p. [In Russian]

Inventory materials of natural complexes and environmental assessment of the territory "Chukozero". Ed. A. N. Gromtsev. Petrozavodsk: KarRC RAS, 2007. 137 p. [In Russian]

Inventory materials of natural complexes and scientific justification of the landscape reserve "Syrovatka". Ed. A. N. Gromtsev. Petrozavodsk: KarRC RAS, 2003. 92 p. [In Russian]

Inventory of biological diversity in the border areas of the Republic of Karelia and Finland. Eds. V. I. Krutov, A. N. Gromtsev. Petrozavodsk: KarRC RAS, 1998. 168 p. [In Russian]

Fedorets N. G., Bakhmet O. N., Morozova R. M. Soils and soil cover of protected areas of Karelia. Petrozavodsk: KarRC RAS, 2009. 109 p. [In Russian]

Kravchenko A. V., Bakalin V., Fadeeva M. et al. Biodiversity of vascular plant, lichen and hepatic flora of the old growth forests in the Green belt of Russian Karelia. Biodiversity of old-growth forests and its conservation in northwestern Russia. Regional Environmental Publications. Vol. 158. Oulu, 2000. P. 7-64.

KryshenA. M., GromtsevA. N., Titov A. F., Danilov P. I., Kuznetsov O. L. Creation and development of a unified system of specially protected natural territories of the European North. The use and protection of natural resources in Russia. 2012. No. 4. P. 54-57. [In Russian]

Kurhinen Yu. P., Danilov P. I., Ivanter E. V. Mammals of Eastern Fennoscandia under anthropogenic transformation of taiga ecosystems. Moscow: Nauka, 2006. 208 p. [In Russian]

Management of tourism development in the region. Experience in implementing the Strategy of the Republic 
of Karelia. Eds. Yu. V. Saveliev, O. V. Tolstoguzov. Petrozavodsk: KarRC RAS, 2008. 227 p. [In Russian]

Mapping of High Conservation Value Areas in Northwestern Russia: Gap-Analysis of the Protected Areas Network in the Murmansk, Leningrad, Arkhangelsk, Vologda, and Karelia regions, and the city of Saint-Petersburg. Ed. K. N. Kobyakov. St. Petersburg, 2011. 506 p. [In Russian]

Morozova T. V. Alternative ways to develop cross-border local communities. Population. 2005. No. 2. P. 71-90. [In Russian]

Morozova T. V., Gurova S. A., Kozireva G. B., Kulakova $L$. M. Socio-economic preconditions for the development of specially protected natural areas in the border zone of the Republic of Karelia. Development of specially protected natural areas in the border zone of the Republic of Karelia. Petrozavodsk; Helsinki, 2001. 67 p.

Rocky landscapes of the Karelian coast of the White Sea: natural features, economic development, conservation measures. Ed. A. N. Gromtsev. Petrozavodsk: KarRC RAS, 2008. 212 p. [In Russian]

\section{СВЕДЕНИЯ ОБ АВТОРАХ:}

\section{Бахмет Ольга Николаевна}

председатель КарНЦ РАН, руководитель Отдела комплексных научных исследований КарНЦ РАН, член-корр. РАН, д. б. н.

Федеральный исследовательский центр

«Карельский научный центр РАН»

ул. Пушкинская, 11, Петрозаводск, Республика Карелия,

Россия, 185910

эл. почта: obahmet@mail.ru

тел.: (8142) 766040

\section{Крышень Александр Михайлович}

директор Института леса КарНЦ РАН, д. б. н.

Федеральный исследовательский центр

«Карельский научный центр РАН»

ул. Пушкинская, 11, Петрозаводск, Республика Карелия, Россия, 185910

эл. почта: kryshen@krc.karelia.ru

тел.: (8142) 768160

\section{Боровичев Евгений Александрович}

заместитель председателя по научной работе, к. б. н.

Институт проблем промышленной экологии Севера

КНЦ РАН, Федеральный исследовательский центр

«Кольский научный центр РАН»

мкр. Академгородок, 14а, Апатиты, Мурманская область, Россия, 184209

эл. почта: borovichyok@mail.ru

тел.: (81555) 79378

\section{Громцев Андрей Николаевич}

главный научный сотрудник Отдела комплексных научных исследований КарНЦ РАН, д. с.-х. н.

Федеральный исследовательский центр

«Карельский научный центр РАН»

ул. Пушкинская, 11, Петрозаводск, Республика Карелия, Россия, 185910

эл. почта: gromtsev@krc.karelia.ru

тел.: (8142) 768160
Scientific basis for the development of a network of specially protected natural areas in the Republic of Karelia. Ed. A. N. Gromtsev. Petrozavodsk: KarRC RAS, 2009. 112 p. [In Russian]

State of the Parks in Finland. Finnish Protected Areas and Their Management from 2000 to 2005. Ed. M. Heinonen. Helsinki: Metsähallitus, 2007. 313 p.

The Red Data Book of the Republic of Karelia. Petrozavodsk: Karelia, 2007. 368 p. [In Russian]

Titov A. F., Butorin A. A., Gromtsev A. N., leshko E. P., Kryshen A. M., Saveliev Yu. V. The Green Belt of Fennoscandia: the State and Perspectives. Transactions of KarRC RAS. 2009. No. 2. P. 3-11. [In Russian]

Titov A., leshko E., Hokkanen T. J., Aho J., Pelkonen $P$. Joint ecological policy: a key element in interregional and international. Karelian biosphere reserve studies. Joensuu, 1995. P. 61-63.

Received July 14, 2021

\section{CONTRIBUTORS:}

\section{Bakhmet, Olga}

Department for Multidisciplinary Scientific Research, Karelian Research Centre, Russian Academy of Sciences 11 Pushkinskaya St., 185910 Petrozavodsk, Karelia, Russia e-mail: obahmet@mail.ru tel.: (8142) 766040

\section{Kryshen, Alexander}

Forest Research Institute, Karelian Research Centre, Russian Academy of Sciences

11 Pushkinskaya St., 185910 Petrozavodsk, Karelia, Russia e-mail: kryshen@krc.karelia.ru tel.: (8142) 768160

\section{Borovichev, Evgeny}

Institute of North Industrial Ecology Problems,

Kola Science Centre, Russian Academy of Sciences

14a Akademgorodok, 184209 Apatity, Murmansk Region,

Russia

e-mail: borovichyok@mail.ru

tel.: (81555) 79378

\section{Gromtsev, Andrey}

Department for Multidisciplinary Scientific Research, Karelian Research Centre, Russian Academy of Sciences 11 Pushkinskaya St., 185910 Petrozavodsk, Karelia, Russia e-mail: gromtsev@krc.karelia.ru

tel.: (8142) 768160 
Кравченко Алексей Васильевич

ведущий научный сотрудник Отдела комплексных научных исследований КарНЦ РАН, к. б. н.

Федеральный исследовательский центр

«Карельский научный центр РАН»

ул. Пушкинская, 11, Петрозаводск, Республика Карелия Россия, 185910

эл. почта: alex.kravchen@mail.ru

тел.: (8142) 768160

\section{Кузнецов Олег Леонидович}

главный научный сотрудник Отдела комплексных научных исследований КарНЦ РАН, д. б. н.

Федеральный исследовательский центр

«Карельский научный центр РАН»

ул. Пушкинская, 11, Петрозаводск, Республика Карелия Россия, 185910

эл. почта: kuznetsov@krc.karelia.ru

тел.: (8142) 768160

\section{Титов Александр Федорович}

главный научный сотрудник Отдела комплексных научных исследований КарНЦ РАН, член-корр. РАН, д. б. н.

Федеральный исследовательский центр

«Карельский научный центр РАН»

ул. Пушкинская, 11, Петрозаводск, Республика Карелия, Россия, 185910

эл. почта: titov@krc.karelia.ru

тел.: (8142) 762706

\section{Петрова Ольга Викторовна}

младший научный сотрудник

Институт проблем промышленной экологии Севера

КНЦ РАН, Федеральный исследовательский центр

«Кольский научный центр РАН»

мкр. Академгородок, 14а, Апатиты, Мурманская область,

Россия, 184209

эл. почта: borovichyok@mail.ru

тел.: (81555) 79378

\section{Маслобоев Владимир Алексеевич}

советник руководителя ФИЦ КНЦ РАН, д. Т. н.

Федеральный исследовательский центр

«Кольский научный центр РАН»

ул. Ферсмана, 14, Апатиты, Мурманская обл., Россия,

184209

эл. почта: masloboev@admksc.apatity.ru

тел.: (81555) 79323

\section{Kravchenko, Alexey}

Department for Multidisciplinary Scientific Research, Karelian Research Centre, Russian Academy of Sciences 11 Pushkinskaya St., 185910 Petrozavodsk, Karelia, Russia e-mail: alex.kravchen@mail.ru

tel.: (8142) 768160

\section{Kuznetsov, Oleg}

Department for Multidisciplinary Scientific Research, Karelian Research Centre, Russian Academy of Sciences 11 Pushkinskaya St., Petrozavodsk, Karelia, Russia, 185910 e-mail: kuznetsov@krc.karelia.ru tel.: (8142) 768160

Titov, Alexander

Department for Multidisciplinary Scientific Research, Karelian Research Centre, Russian Academy of Sciences 11 Pushkinskaya St., Petrozavodsk, Karelia, Russia, 185910 e-mail: titov@krc.karelia.ru

tel.: (8142) 762706

\section{Petrova, Olga}

Institute of North Industrial Ecology Problems,

Kola Science Centre, Russian Academy of Sciences 14a Akademgorodok, 184209 Apatity, Murmansk Region, Russia

e-mail: borovichyok@mail.ru

tel.: (81555) 79378

\section{Masloboev, Vladimir}

Kola Science Centre, Russian Academy of Sciences 14 Fersmana St., 184209 Apatity, Murmansk Region, Russia e-mail: masloboev@admksc.apatity.ru tel.: (81555) 79323 